\title{
Діагностичне значення інтегральних імуногематологічних індексів як маркерів хронічного стресу у курей
}

\author{
Ю. В. Осадча \\ seledat@ukr.net \\ Національний університет біоресурсів і природокористування України, \\ вул. Героїв Оборони, 15, м. Київ, 03041, Україна
}

Вивчення стресів в умовах промислових технологій утримання курей та визначення ступеня впливу технологічних стресорів на їхній фізіологічний стан $€$ необхідною вимогою у розробленні нових методів профілактики стресів через вибір оптимальних способів утримання птиці. Мета досліджень полягала у визначенні інформативності інтегральних імуногематологічних індексів для діагностики стрес-індукованих порушень в організмі курей за впливу технологічного стресору різної інтенсивності. Хронічний технологічний стрес був змодельований довготривалим утриманням курей за підвищеної щільності посадки. Інтенсивність дії стресора визначали за мірою підвищення щільності утримання курей. Інтегральні імуногематологічні індекси розраховували на основі розширеного загального аналізу крові. В організмі курей, які внаслідок тривалого утримання за підвищеної щільності перебували у стані хронічного стресу, виявлено високий рівень ендогенної інтоксикації і порушення імунологічної реактивності, на що вказує підвищення індексу зсуву лейкоцитів та індексу імунореактивності, а також індексів співвідношення: лейкоцитів і ШОЕ; гетерофрілів і лімфооцитів; лімфоцитів і моноцитів; гетерофрілів і моноцитів. За хронічного стресу у курей спостерігали активацію клітинної ланки системи імунітету, активну адаптивну реакцію білої крові, а також переважання реакцій уповільненого типу над гіперчутливістю негайного типу, на що вказують зниження лімфоцитарно-гранулоцитарного, загального, лімфоцитарного індексів та індексу співвідношення лімфоцитів і еозинофрілів. Доведено, що інтегральні імуногематологічні індекси є перспективними маркерами для діагностики хронічного стресу у курей.

Ключові слова: імуногематологічні індекси, кури, стрес, імунологічна реактивність, ендогенна інтоксикація

В умовах зростання спеціалізації, концентрації та інтенсифрікації птахівництва актуальним є вивчення впливу основних технологічних параметрів кліткового утримання на біологічні особливості курей [6]. У період адаптації до технологічних процесів організм птиці постійно зазнає впливу негативних фракторів середовища утримання - стресорів, які через нервову і ендокринну системи призводять до морфологічних і функціональних змін в органах і тканинах, що супроводжується зниженням продуктивності, природної резистентності організму та зміною поведінки курей у групі [10, 34]. Тому вивчення стресів в умовах промислових технологій утримання курей і визначення ступеня впливу зовнішніх фракторів на фрізіологічний стан птиці $€$ необхідною умовою розроблення нових методів профілактики стресів в умовах вибору оптимальних способів їх утримання [18].
Однак єдиного підходу до діагностики стресів у птахівництві досі не існує [3]. Усі методи мають свої переваги і недоліки, що потребує обережного вибору маркера стресу. Водночас переконливо доведена ефективність методів діагностики стресу у курей, заснованих на вивченні гормонального статусу, морфологічних показників крові, базових біохімічних констант організму і показників резистентності, та використання зазначеного підходу для визначення впливу технологічних фракторів на організми птиці, а також відповідності технологічних параметрів фізіологічним потребам курей [7, 33].

Одним 3 непрямих методів оцінки стресового стану у птиці, який базується саме на морфологічних показниках крові, є визначення співвідношення у ній гетерофрілів і лімфоцитів [17, 21, 31]. Оскільки доведено [9], що під час розвитку стресового стану 
цей показник збільшується внаслідок підвищеної проліферації гемопоетичних стовбурових клітин, збільшеного вироблення гетерофілів і за рахунок абортивного викиду незрілих клітин гетерофілів із кісткового мозку у кров і міграції лімфоцитів з нього у тканини. Крім того, зміни співвідношення гетерофілів і лімфоцитів корелюють з концентрацією кортикостерону у крові курей та пропорційні ступеню впливу стресорів різної природи [30, 35].

Співвідношення гетерофрілів і лімфоцитів $є$ інтегральним імуногематологічним індексом, який в гуманній медицині відомий як індекс Кребса [28]. Крім нього, в гуманній медицині використовують цілу панель імуногематологічних індексів, які непрямим чином віддзеркалюють стан імунної системи і характер перебігу запального процесу в організмі $[2,25,26,29]$.

Останнім часом маркерну панель, до якої належать індекс зсуву лейкоцитів (ІЗЛК), індекс співвідношення нейтрофілів і лімфроцитів (ICHЛ або індекс Кребса), індекс співвідношення лейкоцитів і ШОЕ (IЛШОЕ), лімфоцитарно-гранулоцитарний індекс (ІІГ), загальний індекс (ЗІ), індекс імунореактивності (IIP), індекс співвідношення нейтрофілів і моноцитів (ICHM), індекс співвідношення лімфоцитів і моноцитів (ІСЛМ), лейкоцитарний індекс (ЛІ) та індекс співвідношення лімфоцитів і еозинофрілів (ІСЛЕ), використовують і у тваринництві $[1,13,27,37]$.

Відомо, що переущільнення як спосіб ресурсозбереження у птахівництві провокує в курей стан фрустрації, який може повторюватися кожні 1-2 год. і тривати до знесення чергового яйця. Постійне перебування курей у стані фрустрації призводить до хронічного стресу [15]. Тому мета роботи полягала у визначенні інформативності інтегральних імуногематологічних індексів як маркерів стресу в курей за впливу хронічного переущільнення.

\section{Матеріали і методи}

В умовах сучасного комплексу з виробництва харчових яєць сформували чотири групи курей промислового стада кросу «Hy-Line W-36» (табл. 1), кожну з яких утримували в окремому пташнику-аналогу за площею (2640 м²), обладнаному 12-ярусними клітковими батареями «Salmet» (Німеччина), які складалися з 18144 кліток площею $7506 \mathrm{~cm}^{2}(120 \times 62,55 \mathrm{~cm})$.

Хронічний стрес було змодельовано 33-тижневим утриманням курей, а саме від початку несучості (у 19-тижневому віці) і до 52-тижневого віку за різної щільності утримання. Згідно з вітчизняними нормами (ВНТП-АПК-04.05.), щільність утримання курей у клітках має бути в межах 22-25 гол./м² (забезпеченість площею 400-450 см²/гол.), а відповідно до вимог настанови розробника кросу (Hy-Line W-36 Final Hybrid Content Guide, 2019) - в межах 13-20 гол/ $/ \mathrm{M}^{2}$ (490-750 cм²/гол.) і за забезпеченістю фронтом годівлі не менше, ніж 7,0 cм/гол. Як свідчать дані
Таблиця 1. Схема досліду

Table 1. The scheme of the experiment

\begin{tabular}{|c|c|c|c|c|}
\hline \multirow{2}{*}{$\begin{array}{l}\text { Характеристика } \\
\text { Characteristic }\end{array}$} & \multicolumn{4}{|c|}{ Група курей / Group of hens } \\
\hline & 1 & 2 & 3 & 4 \\
\hline $\begin{array}{l}\text { Кількість птахів у клітці } \\
\text { Number of hens in the cage }\end{array}$ & 10 & 18 & 19 & 20 \\
\hline $\begin{array}{l}\text { Кількість птахів у групі } \\
\text { Number of hens in the group }\end{array}$ & 181440 & 326592 & 344736 & 362880 \\
\hline $\begin{array}{l}\text { Щільність посадки, гол./M² } \\
\text { Planting density, hens } / \mathrm{m}^{2}\end{array}$ & 13,3 & 24,0 & 25,3 & 26,7 \\
\hline $\begin{array}{l}\text { Забезпеченість площею, } \\
\text { см}^{2} / \text { гол. } \\
\text { Provision of area, } \mathrm{cm}^{2} / \text { hen }\end{array}$ & 750,6 & 417,0 & 395,1 & 375,3 \\
\hline $\begin{array}{l}\text { Фронт годівлі, см } \\
\text { Front of feeding, } \mathrm{cm}\end{array}$ & 12,0 & 6,7 & 6,3 & 6,0 \\
\hline
\end{tabular}

табл. 1, щільність утримання курей 1-ї групи відповідала європейським нормам і вимогам розробника кросу, 2-ї групи - вітчизняним нормам, а курей 3- та 4-ї груп утримували з наростанням переущільнення. Таким способом моделювали поступове наростання інтенсивності технологічного стресора.

Упродовж досліду курей забезпечували питною водою, повнораціонними комбікормами однакового складу й утримували згідно з вимогами (ВНТПАПК-04.05.). Відмінність між групами полягала лише у щільності утримання несучок, рівень якої залежав від їхньої кількості у клітках, що призводило до різної забезпеченості фрронтом годівлі.

Морфологічні показники крові курей-несучок визначали на гематологічному аналізаторі Micros 60 (Horiba Ltd.) у лабораторії «Бальд» (сертифрікат №LB/02/2016). Для цього брали по 30 проб крові у несучок кожної групи у віці 52 тижні. Відбирали по 1,0-1,5 мл крові з підкрильцевої вени у пробірку з EDTA.

Для оцінки адаптаційного і загального реактивного імунологічного потенціалу курей визначали інтегральні імуногематологічні індекси: інтоксикації індекс зсуву лейкоцитів (ІЗЛК); активності запалення - індекс співвідношення гетерофрілів і лімфоцитів (ІСГЛ або індекс Кребса) або гетерофрільно-лімфоцитарний коефріцієнт, індекс співвідношення лейкоцитів і ШОЕ (ІЛШОЕ), лімфоцитарно-гранулоцитарний індекс (ІЛГ), загальний індекс (3І); неспецифічної реактивності - індекс імунореактивності (IIP), індекс співвідношення гетерофрілів і моноцитів (ICГM), індекс співвідношення лімфоцитів і моноцитів (ІСЛМ), лейкоцитарний індекс (ЛІ), індекс співвідношення лімфоцитів і еозинофрілів (ІСЛЕ) [14, 22, 25, 28].

Для визначення інформативності змін показників системи імунітету як можливих прогностичних чинників досліджували ступінь імунологічних порушень (СІП). За наявності імунодесріциту показник був негативним «-», знак «+» свідчив про гіперфуннкцію імунної системи. Значення результату в межах 1-33\% тракту- 
вали як I ступінь імунологічних розладів, 34-66,7\% II ступінь, понад 66,7\% - III ступінь [2].

Отримані цифрові результати опрацьовували методами варіаційної статистики. Вірогідність відмінностей між середніми величинами визначали за $t$-критерієм Стьюдента, різниці вважали вірогідними за $\mathrm{P}<0,05$.

\section{Результати й обговорення}

Виявлено, що лімфоцитарний індекс (ЛІ), лімфоцитарно-гранулоцитарний індекс (ІЛГ), загальний індекс (3І) та індекс співвідношення лімфоцитів і еозинофрілів (ICЛЕ) знижувалися з підвищенням щільності утримання курей, тоді як індекс зсуву лейкоцитів (ІЗЛК), індекс імунореактивності (IIP), індекс співвідношення лейкоцитів і ШОЕ (ІЛШОЕ), індекс співвідношення гетерофілів і лімфоцитів (ІСГЛ), індекс співвідношення лімфоцитів і моноцитів (ICЛМ) та індекс співвідношення гетерофрілів і моноцитів (ІСГМ) навпаки, підвищувались (табл. 2).
Індекс зсуву лейкоцитів (ІЗЛК), який характеризує співвідношення гранулоцитів та агранулоцитів і не залежить від кількості лейкоцитів у крові [26], підвищувався з посиленням дії стресору. Він виявився вищим в курей 4-ї групи - на 0,52 од. або 136,8\% $(\mathrm{P}<0,001)$ порівняно з 1-ю групою, на 0,43 од. або $91,5 \%(P<0,001)$ і 0,38 од. або 73,1\% ( $P<0,001)$ порівняно з 2- та 3-ю групами відповідно. Водночас у курей 2-ї групи ІЗЛК був вищим на 0,09 од. або $23,7 \%$ ( $P<0,001)$, а у курей 3-ї групи - на 0,14 од. або $36,8 \%$ порівняно з 1-ю групою. Різниця ІЗЛК між 2- та 3-ю групами становила лише 0,05 од. або 10,6\% і статистично не підтвердилась. Підвищення ІЗЛК з посиленням інтенсивності дії стресора вказує на зсув лейкоцитарної формули вліво, що свідчить про порушення імунологічної реактивності [36] і надходження до периферійної крові великої кількості «молодих» фрорм лейкоцитів [26].

Індекс співвідношення гетерофрілів та лімфоцитів (ІСГЛ або індекс Кребса), який класично є маркером стресу $[13,21]$ та відображає співвідношення клітин

Таблиця 2. Інтегральні імуногематологічні індекси курей

Table 2. Integral immunohematological indices of hens

\begin{tabular}{|c|c|c|c|c|}
\hline \multirow{2}{*}{ Індекс,од. / Index, un. } & \multicolumn{4}{|c|}{ Група курей / Group of hens } \\
\hline & 1 & 2 & 3 & 4 \\
\hline \multicolumn{5}{|c|}{ Індекси інтоксикації / Intoxication index } \\
\hline $\begin{array}{l}\text { Індекс зсуву лейкоцитів } \\
\text { Leukocyte shift index }\end{array}$ & $0,38 \pm 0,006$ & $0,47 \pm 0,015^{\star \star *}$ & $0,52 \pm 0,029 * * *$ & $0,90 \pm 0,097^{* * * \circ \circ \div " ' ~}$ \\
\hline \multicolumn{5}{|c|}{ Індекси активності запалення / Inflammatory activity index } \\
\hline $\begin{array}{l}\text { Індекс співвідношення гетерофрілів } \\
\text { і лімфоцитів (Індекс Кребса) } \\
\text { Heterophil to lymphocyte ratio (Krebs index) }\end{array}$ & $0,35 \pm 0,013$ & $0,39 \pm 0,002^{* *}$ & $0,43 \pm 0,033^{*}$ & $0,76 \pm 0,078^{* \star * \circ \circ \circ " ' ~}$ \\
\hline $\begin{array}{l}\text { Лімфоцитарно-гранулоцитарний індекс } \\
\text { Lymphocyte-granulocyte index }\end{array}$ & $17,73 \pm 0,433$ & $16,34 \pm 0,164^{\star *}$ & $16,14 \pm 0,633^{*}$ & $11,89 \pm 0,931^{* * * \circ \circ \circ ! \prime \prime}$ \\
\hline $\begin{array}{l}\text { Індекс співвідношення лейкоцитів і шОЕ } \\
\text { Leukocyte to erythrocyte sedimentation rate ratio }\end{array}$ & $0,35 \pm 0,009$ & $0,80 \pm 0,005^{\star * *}$ & $0,86 \pm 0,004^{* * * \circ \circ}$ & 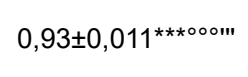 \\
\hline $\begin{array}{l}\text { Загальний індекс } \\
\text { General index }\end{array}$ & $18,08 \pm 0,438$ & $17,14 \pm 0,108^{*}$ & $17,49 \pm 0,993$ & $12,82 \pm 0,878^{* * * \circ \circ \circ ! \prime}$ \\
\hline \multicolumn{5}{|c|}{ Індекси неспецифічної реактивності / Indices of nonspecific reactivity } \\
\hline $\begin{array}{l}\text { Індекс імунореактивності } \\
\text { Immunoreactivity index }\end{array}$ & $7,92 \pm 0,271$ & $10,78 \pm 0,102^{\star \star \star}$ & $13,19 \pm 0,325^{\star * * \circ \circ \circ}$ & $15,75 \pm 0,813^{* * * \circ \circ \bullet "}$ \\
\hline $\begin{array}{l}\text { Індекс співвідношення гетерофрілів і моноцитів } \\
\text { Heterophil to monocyte ratio }\end{array}$ & $2,61 \pm 0,039$ & $3,90 \pm 0,067^{* * *}$ & $5,42 \pm 0,534^{* * * \circ \circ}$ & $18,48 \pm 0,973^{* * * \circ \circ \circ ! \prime}$ \\
\hline $\begin{array}{l}\text { Індекс співвідношення лімфоцитів і моноцитів } \\
\text { Lymphocyte to monocyte ratio }\end{array}$ & $7,62 \pm 0,254$ & $10,03 \pm 0,132^{\star \star *}$ & $12,20 \pm 0,400^{* * * \circ \circ \circ}$ & $20,65 \pm 1,873^{* * * \circ \circ \circ ! "}$ \\
\hline $\begin{array}{l}\text { Лімфоцитарний індекс } \\
\text { Lymphocytic index }\end{array}$ & $2,96 \pm 0,131$ & $2,57 \pm 0,013^{\star \star *}$ & $2,25 \pm 0,118^{* * * \circ \circ}$ & $1,65 \pm 0,143^{* * * \circ \circ ! "}$ \\
\hline $\begin{array}{l}\text { Індекс співвідношення лімфоцитів і еозинофрілів } \\
\text { Lymphocyte to eosinophil ratio }\end{array}$ & $21,08 \pm 0,207$ & $14,30 \pm 0,974^{* * *}$ & $14,84 \pm 1,504^{\star * *}$ & $11,08 \pm 0,973^{* * * 01}$ \\
\hline
\end{tabular}

Примітка. * - $\mathrm{P}<0,05,{ }^{* *}-\mathrm{P}<0,01,{ }^{* * *}-\mathrm{P}<0,001-$ порівняно 3 1-ю групою; ${ }^{\circ}-\mathrm{P}<0,05,{ }^{\circ \circ}-\mathrm{P}<0,01,{ }^{\circ \circ 0}-\mathrm{P}<0,001-$ порівняно з 2-ю групою; ' $-\mathrm{P}<0,05$, " - $\mathrm{P}<0,01$; "' $-\mathrm{P}<0,001-$ порівняно з 3-ю групою.

Note. ${ }^{*}-\mathrm{P}<0.05,{ }^{* *}-\mathrm{P}<0.01,{ }^{* * *}-\mathrm{P}<0.001$ - compared with the $1^{\text {st }}$ group; ${ }^{\circ}-\mathrm{P}<0.05,{ }^{\circ \circ}-\mathrm{P}<0.01,{ }^{\circ \circ 0}-\mathrm{P}<0.001-$ compared with the $2^{\text {nd }}$ group; ' $-\mathrm{P}<0.05$, " $-\mathrm{P}<0.01$, " $-\mathrm{P}<0.001-$ compared with the $3^{\text {rd }}$ group. 
специфічного і неспецифрічного імунітету [20], підвищувався з посиленням дії стресора. Найвищий ІСГЛ виявлений у курей 4-ї групи - на 0,41 од. або $117,1 \%(P<0,001)$ порівняно з 1-ю групою, на 0,37 од. або $94,9 \%(P<0,001)$ і 0,33 од. або 76,7\% $(P<0,001)$ порівняно з 2- та 3-ю групами відповідно. У курей 2-ї групи ІСГЛ був вищим на 0,04 од. або 11,4\% (P<0,01), а у курей 3-ї групи - на 0,08 од. або 22,9\% $(P<0,05)$ порівняно з 1-ї групою. Різниця між 2- та 3-ю групами становила лише 0,04 од. або 10,3\% і статистично не підтвердилась. ІСГЛ характеризує активність фагоцитарних реакцій і факторів специфічного імунітету, а також їхню участь у підтримці загальної реактивності організму [26], тому його підвищення з посиленням дії стресора свідчить про перевагу неспецифічних захисних клітин, що відбувається внаслідок функціонального підвищення проліферативної активності кісткового мозку і виражається у збільшенні кількості гетерофрілів [8].

Лімфоцитарно-гранулоцитарний індекс (ІЛГ), який дозволяє диференціювати автоінтоксикацію, викликану порушенням роботи імунної або фрерментативної системи, та інфрекційну інтоксикацію, а також виражає в числах ступінь зсуву лейкоцитарної формули крові $[12,14]$, знижувався з посиленням дії стресора. Найнижчий ІЛГ виявлено у курей 4-ї групи - на 5,84 од. або 49,1\% ( $P<0,001), 4,45$ од. або $37,4 \%(P<0,001)$ та 4,74 од. або 39,9\% ( $\mathrm{P}<0,001)$ порівняно з 1-, 2-ю та 3-ю групами відповідно. У курей 2-ї та 3-ї груп ІЛГ був нижчим на 1,39 од. або 8,5\% $(P<0,001)$ та 1,59 од. або 9,9\% $(P<0,05)$, ніж у $1-и ̆$ групі. Різниця між 2-ю та 3-ю групами статистично не підтвердилась. Зниження ІЛГ свідчить про зсув лейкоцитарної фоомули вліво та підтверджує наявність автоімунної інтоксикації $[12,23,29]$. Зниження ІЛГ також можна розглядати як порушення чинників і механізмів імунологічної реактивності [16]. Одночасне підвищення ІЗЛК та зниження ІЛГ свідчить про розвиток ендогенної інтоксикації і порушення імунологічної реактивності внаслідок автоінтоксикації організму під час деструкції власних клітин [22].

Індекс співвідношення лейкоцитів і ШОЕ (ІЛШОЕ), зміни якого свідчать про наявність інтоксикації, пов'язаної з інфекційним (зменшення ІЛШОЕ) або автоімунним (збільшення ІЛШОЕ) процесом [19], підвищувався з посиленням дії стресора. Найвищий ІЛШОЕ спостерігали в курей 4-ї групи - на 0,58 од. або $165,7 \%(P<0,001)$ порівняно з 1 -ю групою та на 0,13 од. або $16,3 \%(P<0,001)$ і 0,07 од. або $8,1 \%$ $(\mathrm{P}<0,001)$ порівняно з 2- та 3-ю групами відповідно. Водночас ІЛШОЕ у курей 2-ї групи був вищим на 0,45 од. або $128,6 \%(P<0,001)$ порівняно з 1 -ю групою, а в курей 3-ї групи - на 0,51 од. або $145,7 \%$ $(P<0,001)$ і 0,06 од. або $7,5 \%(P<0,001)$ порівняно з 1-ю та 2-ю групами відповідно. Підвищення ІЛШОЕ з посиленням дії стресора вказує на наявність в організмі курей вираженої системної запальної відповіді з високим рівнем ендогенної інтоксикації і порушен- ням імунологічної реактивності [29], а також підтверджує автоімунний характер патологічного процесу [2, 22, 28, 38].

Загальний індекс (ЗІ), який є сумою лімфоцитарногранулоцитарного (ІЛГ) і співвідношення лейкоцитів і ШОЕ (ІЛШОЕ) індексів та дозволяє розрізнити характер інтоксикації на ранніх стадіях розвитку патологічного процесу [22], знижувався з підвищенням сили впливу стресора. Найнижчий ЗІ виявлено в курей 4-ї групи - на 5,26 од. або 41,0\% (P<0,001), ніж у курей 1-ї групи, на 4,32 од. або 35,2\% ( $\mathrm{P}<0,001)$ і на 4,67 од. або $36,4 \%(P<0,001)-$ ніж у курей 2-ї та 3-ї груп відповідно. Варто зазначити, що різниця 3І між 1-ю та 2-ю групами становила лише 0,94 од. або 5,5\% ( $P<0,05)$, а між відмінностей між 1-ю та 3-ю, а також 2-ю та 3-ю групами не виявлено. Зниження 3І свідчить про наявність в організмі курей інтоксикаційного процесу [27].

Індекс імунореактивності (IIP), який відображає стан основних клітин-продуцентів цитокінів та дисбаланс у цитокіновому профілі [32], підвищувався з посиленням дії стрес-фрактора. Найвищий IIP спостерігали у курей 4-ї групи - на 7,83 од. або 98,9\% (P<0,001), ніж в курей 1-ї групи, на 4,97 од. або 46,1\% ( $P<0,001)$ і на 2,56 од. або 19,4\% (P<0,01) - ніж в курей 2- та 3-ї груп відповідно. Водночас у курей 2-ї групи IIP був вищим на 2,86 од. або $36,1 \%(P<0,001)$ порівняно 3 1-ю групою, а у курей 3-ї групи - на 5,27 од. або 66,5\% $(P<0,001)$ порівняно з 1-ю групою та на 2,41 од. або $47,3 \%$ ( $P<0,001)$ порівняно з 2-ю групою. Підвищення IIP з посиленням дії стресору свідчить у курей 3-ї і 4-ї груп про декомпенсацію, а в курей 2-ї групи - про субкомпенсацію ендогенної інтоксикації [11].

Індекс співвідношення гетерофілів і моноцитів (ІСГМ), який свідчить про співвідношення компонентів мікрофрагально-макрофрагальної системи [29], підвищувався з посиленням дії стрес-фрактора. Найвищий ІСГМ спостерігали в курей 4-ї групи на 15,87 од. або $608,0 \%(P<0,001)$ порівняно 3 1-ю групою,на 14,58 од. або $373,8 \%(P<0,001)$ і 13,06 од. або 241,0\% ( $P<0,001)$ порівняно з 2-ю та 3-ю групами відповідно. Водночас кури 2-ї групи характеризувались вищим ICHМ на 1,29 од. або 49,4\% (P<0,001) порівняно з 1-ю групою, а кури 3-ї групи - на 2,81 од. або $107,7 \%(P<0,001)$ і 1,52 од. або 39,0\% $(P<0,01)$ порівняно з 1-ю та 2-ю групами відповідно. Підвищення ICГМ з посиленням дії стресора вказує на підвищення активності гетерофрілів у мікрофрагальномакрофрагальній системі імунної відповіді [24].

Індекс співвідношення лімфоцитів і моноцитів (ICЛМ), який відображає взаємовідношення афекторної й ефекторної ланок імунологічного процесу [4], підвищувався з посиленням дії стрес-фрактора. Найвищий ІСЛМ виявлено у курей 4-ї групи на 13,03 од. або $171,0 \%(P<0,001)$ порівняно 3 1-ю групою, на 10,62 од. або 105,9\% (P<0,001) і 8,45 од. або 69,3\% (P<0,001) порівняно з 2-ю та 3-ю групами відповідно. Водночас у курей 2-ї групи ІСЛМ був 
вищим на 2,68 од. або 35,2\% ( $P<0,001)$ порівняно 31 -ю групою, а у курей 3-ї групи - на 4,58 од. або $60,1 \%$ $(\mathrm{P}<0,001)$ порівняно з 1-ю групою та на 2,17 од. або $21,6 \%(P<0,001)$ порівняно з 2-ю групою. Підвищення ІСЛМ свідчить про переважання ефекторної ланки імунологічного процесу над афректорною [27].

Лімфоцитарний індекс (ЛІ), який відображає взаємовідношення гуморальної та клітинної ланок імунної системи [22], знижується з посиленням дії стресора. Так, ЛІ в курей 2-ї був нижчим на 0,39 од. або 15,2\% $(\mathrm{P}<0,001)$ порівняно з 1-ю групою, а в курей 3-ї групи - на 0,71 од. або $31,6 \%$ (P<0,001) та 0,32 од. або $14,2 \%(P<0,01)$ порівняно з 1- та 2-ю групами відповідно. У курей 4-ї групи ЛІ був нижчим на 1,31 од. або $79,4 \%(P<0,001)$ порівняно з 1-ю групою, на 0,92 од. або $55,8 \%(P<0,001)$ і 0,6 од. або $36,4 \%(P<0,001)$ порівняно з 2- та 3-ю групами відповідно. Зниження ЛІ

Таблиця 3. Ступінь імунологічних порушень за індексами крові курей

Table 3. The degree of immunological disorders by blood indices of hens

\begin{tabular}{|c|c|c|c|}
\hline \multirow{2}{*}{$\begin{array}{l}\text { Індекс, од. } \\
\text { Index, un. }\end{array}$} & \multicolumn{3}{|c|}{$\begin{array}{l}\text { Група курей } \\
\text { Group of hens }\end{array}$} \\
\hline & 2 & 3 & 4 \\
\hline \multicolumn{4}{|l|}{$\begin{array}{l}\text { Індекси інтоксикації } \\
\text { Intoxication index }\end{array}$} \\
\hline $\begin{array}{l}\text { Індекс зсуву лейкоцитів } \\
\text { Leukocyte shift index }\end{array}$ & +1 & +11 & + III \\
\hline \multicolumn{4}{|c|}{$\begin{array}{l}\text { Індекси активності запалення } \\
\text { Inflammatory activity index }\end{array}$} \\
\hline $\begin{array}{l}\text { Індекс співвідношення гетерофрілів } \\
\text { і лімфооцитів (Індекс Кребса) } \\
\text { Heterophil to lymphocyte ratio (Krebs index) }\end{array}$ & +1 & +1 & + III \\
\hline $\begin{array}{l}\text { Лімфоцитарно-гранулоцитарний індекс } \\
\text { Lymphocyte-granulocyte index }\end{array}$ & -1 & -1 & -1 \\
\hline $\begin{array}{l}\text { Індекс співвідношення лейкоцитів і ШОЕ } \\
\text { Leukocyte to erythrocyte } \\
\text { sedimentation rate ratio }\end{array}$ & + III & + III & $+\mid I I$ \\
\hline $\begin{array}{l}\text { Загальний індекс } \\
\text { General index }\end{array}$ & -1 & -1 & -1 \\
\hline \multicolumn{4}{|c|}{$\begin{array}{l}\text { Індекси неспецифічної реактивності } \\
\text { Indices of nonspecific reactivity }\end{array}$} \\
\hline $\begin{array}{l}\text { Індекс імунореактивності } \\
\text { Immunoreactivity index }\end{array}$ & $+I I$ & +11 & $+I I I$ \\
\hline $\begin{array}{l}\text { Індекс співвідношення } \\
\text { гетерофілів і моноцитів } \\
\text { Heterophil to monocyte ratio }\end{array}$ & + +III & + III & + III \\
\hline $\begin{array}{l}\text { Індекс співвідношення } \\
\text { лімфоцитів і моноцитів } \\
\text { Lymphocyte to monocyte ratio }\end{array}$ & +1 & $+I I$ & $+\mid I I$ \\
\hline $\begin{array}{l}\text { Лімфоцитарний індекс } \\
\text { Lymphocytic index }\end{array}$ & -1 & -1 & -11 \\
\hline $\begin{array}{l}\text { Індекс співвідношення } \\
\text { лімфоцитів і еозинофрілів } \\
\text { Lymphocyte to eosinophil ratio }\end{array}$ & -1 & -1 & $-I I$ \\
\hline
\end{tabular}

свідчить про активацію клітинної ланки системи імунітету, а також вказує на активну адаптивну реакцію білої крові та зниження неспецифічного протиінфекційного захисту внаслідок інтоксикації [27].

Індекс співвідношення лімфоцитів і еозинофрілів (ІСЛЕ), який відображає співвідношення процесів гіперчутливості негайного і сповільненого типу [22], також знижувався з підвищенням сили впливу стресора. ІСЛЕ виявився найнижчим в курей 4-ї групи, де вплив стресора був найінтенсивнішим, - на 10,0 од. або $90,3 \%(P<0,001)$ порівняно з 1-ю групою, на 3,22 од. або $29,1 \%(P<0,05)$ і 3,76 од. або $33,9 \%$ $(\mathrm{P}<0,05)$ порівняно з 2-ю та 3-ю групами відповідно. ІСЛЕ у курей 2-ї групи був нижчим на 6,78 од. або $47,4 \%(P<0,001)$, а у курей 3-ї групи - на 6,24 од. або 42,0\% (P<0,001) порівняно з 1-ю групою. Різниці ICЛЕ між 2-ю та 3-ю групами не спостерігали. Зниження ICЛЕ відображає переважання реакцій уповільненого типу над гіперчутливістю негайного типу, що призводить до запуску алергічних механізмів на тлі інтоксикації [5].

Визначення інформативності змін інтегральних імуногематологічних індексів як показників системи імунітету показало, що всі вони певною мірою відображали реакцію організму курей на вплив технологічного стресора (табл. 3).

Інформативними індексами, які відреагували на ступінь інтенсивності дії стрес-фрактора, виявились ІЗЛК, ІСГЛ (IК), IIP, ІСЛМ, ЛІ та ІСЛЕ. Серед них найчутливішими інтегральними імуногематологічними індексами, які відобразили I, II та III ступінь імунологічних порушень пропорційно до наростання інтенсивності стресора, є ІЗЛК та ІСЛМ.

\section{Висновки}

Комплексна оцінка інтегральних імуногематологічних індексів на основі розширеного загального аналізу крові $€$ інформативною в оцінці розвитку та ступеня тяжкості стресового стану організму курей. В курей у стані хронічного стресу спостерігали підвищення індексів ІЗЛК, ІСГЛ, ІЛШОЕ, ІІР, ІСГМ та ІСЛМ, що вказує на зсув лейкоцитарної формули вліво, перевагу неспецифічних захисних клітин, що відбувається внаслідок функціонального підвищення проліфреративної активності кісткового мозку і виражається у збільшенні кількості гетерофрілів, підвищенні їхньої активності у мікрофрагально-макрофрагальній системі імунної відповіді та свідчить про наявність в організмі курей ендогенної інтоксикації і порушення імунологічної реактивності, а також підтверджує автоімунний характер патологічного процесу. Водночас відбувається зниження індексів ІЛГ, ЗІ, ЛІ та ICЛЕ, що підтверджує зсув лейкоцитарної формули вліво і свідчить про активацію клітинної ланки системи імунітету, вказує на активну адаптивну реакцію білої крові та зниження неспецифічного протиінфрекційного 
захисту внаслідок інтоксикації, а також відображає переважання реакцій уповільненого типу над гіперчутливістю негайного типу, що призводить до запуску алергічних механізмів на тлі інтоксикації. Одночасне підвищення ІЗЛК та зниження ІЛГ свідчить про розвиток ендогенної інтоксикації в курей та порушення у них імунологічної реактивності внаслідок автоінтоксикації організму під час деструкції власних клітин.

\section{Перспективи подальших досліджень}

Подальші дослідження будуть скеровані на вивчення стрес-індукованих порушень в організмі курей, спричинених іншими технологічними стресорами, з використанням інтегральних імуногематологічних індексів.

1. Belyaeva EY, Buslovskaya LK. Adaptive reactions and biochemical parameters of the blood of chickens under different light conditions. Sci. Bull. Belgorod State Univer., Ser. Nat. Sci. 2012; 21 (140), 21/1: 143-148. Available at: http://dspace.bsu.edu.ru/ handle/123456789/18540 (in Russian)

2. Bondarchuk IV, Sydorchuk LP, Sydorchuk IY. Adaptation stress level and cell reactivity in arterial hypertensive patients with coronary heart disease. Bukovynian Med. Bull. 2016; 20 (2/78): 16-19. DOI: 10.24061/2413-0737.XX.2.78.2016.62. (in Ukrainian)

3. Dawkins MS. Behavior as a tool in the assessment of animal welfare Zool. 2003; 106 (4): 383-387. DOI: 10.1078/0944-2006-00122.

4. Derkho MA, Samoilova ES. Integral indices of intoxication as a criterion for assessing the level of endogenous intoxication in babesiosis. Sci. Notes KSAVM N. E. Bauman. 2011; 207 170-177. (in Russian)

5. Djuriak VS. Cellular reactivity and stress level adaptivity of patients with community acquired pneumonia. Clin. Exp. Pathol. 2015; 14 (4): 32-35. DOI: 10.24061/1727-4338.XIV.4.54.2015.8. (in Ukrainian)

6. Fisinin VI, Papazyan T, Suray P. Innovative methods of dealing with stress in poultry. Poultry Prod. 2009; 8: 10-14. (in Russian)

7. Flügge G. Effects of cortisol on brain alpha2-adrenoceptors: potential role in stress. Neurosci. Biobehav. Rev. 1999; 23 (7): 949-956. DOI: 10.1016/S0149-7634(99)00028-7.

8. Gao SQ, Huang LD, Dai RJ, Chen DD, Hu WJ, Shan YF Neutrophil-lymphocyte ratio: a controversial marker in predicting Crohn's disease severity. Int. J. Clin. Exp. Pathol. 2015; 8 (11): 14779-14785. PMID: 26823804

9. Heidt T, Sager HB, Courties G, Dutta P, Iwamoto Y, Zaltsman A von Zur Muhlen C, Bode C, Fricchione GL, Denninger J, Lin CP Vinegoni C, Libby P, Swirski FK, Weissleder R, Nahrendorf M. Chronic variable stress activates hematopoietic stem cells. Nat. Med. 2014; 20 (7): 754-758. DOI: 10.1038/nm.3589.

10. Kavtarashvili AS, Kolokolnikova TN. Physiology and productivity of poultry under stress (review). Agricul. Biol. 2010; 4: 25-37. Available at: http://www.agrobiology.ru/4-2010kavtarashvili.html (in Russian)

11. Khabirov TS. The level of the reactive response of neutrophils as an indicator of the severity of endogenous intoxication in abdominal sepsis. Proc. IX SFULT Congress, Luhansk. 2002: 223. (in Russian)

12. Kholodkovskaya VD, Barabanov AL. Using integral hematological indices to assess severity of endogenous toxicosis in chronic dermatoses. Internat. Sci. Pract. Conf. "World Sci.". 2015; 3 (2): 69-72.

13. Letkin Al. Leukocytal indexes of laying hen blood in nonspecific stress syndrome. Bull. Altai State Agr. Univer. 2020; 2 (184): 102108. Available at: http://www.asau.ru/vestnik/2020/2/102-108.pdf (in Russian)
14. Lewandowski RA. Cellular and immunological reactivity of the organism in patients after resection of the upper and lower jaws for the removal of malignant tumors. Clinical and experimental pathology. 2014; 12 (2): 83-87. (in Ukrainian)

15. Marino L. Thinking chickens: a review of cognition, emotion, and behavior in the domestic chicken. Anim. Cognition. 2017; 20: 127-147. DOI: 10.1007/s10071-016-1064-4.

16. Matolic UD. Diagnostic value of hematological indices in phlegmons of the maxillofacial area and neck. Sci. Bull. Uzhhorod Univer. Med. Ser. 2016; 1 (53): 108-110. (in Ukrainian)

17. Maxwell MH, Hocking PM, Robertson GW. Differential leucocyte responses to various degrees of food restriction in broilers, turkeys and ducks. Brit. Poult. Sci. 1992; 33 (1): 177-187. DOI: 10.1080/00071669208417455.

18. Miftakhutdinov AV. Experimental approaches to stress diagnostics in poultry (review). Agricult. Biol. 2014; 2: 20-30. DOI: 10.15389/ agrobiology.2014.2.20eng. (in Russian)

19. Mustafina ZG, Kramarenko YS, Kobtseva VY. Integral hematological parameters in the assessment of the body's immunological reactivity in patients with ophthalmopathology. Clin. Lab. Diagnost. 1999; 5: 47-48. (in Russian)

20. Nikiforov A. Neurology: a complete explanatory dictionary. Moscow, Eksmo. 2010; 464. (in Russian)

21. Nwaigwe CU, Ihedioha JI, Shoyinka SV, Nwaigwe CO. Evaluation of the hematological and clinical biochemical markers of stress in broiler chickens. Vet. World. 2020; 13 (10): 2294-2300. DOI: 10.14202/vetworld.2020.2294-2300.

22. Ostrovska LY, Moshel TM, Ivanytskiy IO. Analysis of haemograms in patients with inflammatory and inflammatory-dystrophic changes of periodontal tissue. Bull. Probl. Biol. Med. 2016; 1 (126): 360-363. Available at: https://vpbm.com.ua/ua/vpbm-2016-011/7565 (in Ukrainian)

23. Ostrovsky VK. On the indicators of the norm of the leukocyte index of intoxication. Clin. Lab. Diagnost. 2003; 1: 45-46. (in Russian)

24. Sierzega M, Lenart M, Rutkowska M, Surman M, Mytar B, Matyja A, Siedlar M, Kulig J. Preoperative neutrophil-lymphocyte and lymphocyte-monocyte ratios reflect immune cell population rearrangement in resectable pancreatic cancer. Ann. Surg. Oncol. 2017; 24 (3): 808-815. DOI: 10.1245/s10434-016-5634-0.

25. Sipliviy VA, Kohn EV, Evtushenko DV. Application of the leukocyte indices for prognostication of peritonitis outcome. Clin. Surg. 2009; 9: 21-26. (in Russian)

26. Tkachenko EA, Derkho MA. Leukocyte indices in experimental cadmium intoxication in mice. Proc. Orenburg State Agr. Univer. 2014; 3: 81-83. (in Russian)

27. Radzykhovskii ML, Goralskii LP, Borissevich BV, Dyshkant OV. Integral indexes of intoxication in caninae coronaviridae enteritis. Sci. Bull. Vet. Med. 2018; 2: 13-19. DOI: 10.33245/2310-49022018-144-2-13-19. (in Ukrainian)

28. Raznatovskaya EN. Integral indices of endogenous intoxication in patients with chemoresistant pulmonary tuberculosis. Curr. Iss. Pharm. Med. Sci. Pract. 2012; 2 (9): 119-120. (in Russian)

29. Rekalova OM, Panasyukova OR, Koval NG. The use of leukocyte indices in immunological evaluation of inflammatory activity in patients with chronic obstructive pulmonary disease. Asthma Allergy. 2017; 1: 27-33. Available at: http://www.ifp.kiev.ua/doc/ journals/aa/17/pdf17-1/27.pdf (in Ukrainian)

30. Rushen J. Problems associated with the interpretation of physiological data in the assessment of animal welfare. Appl. Anim. Behaviour Sci. 1991; 28 (4): 381-386. DOI: 10.1016/0168-1591(91) 90170-3.

31. Scanes CG. Biology of stress in poultry with emphasis on glucocorticoids and the heterophil to lymphocyte ratio. Poult. Sci. 2016; 95 (9): 2208-2215. DOI: 10.3382/ps/pew137.

32. Shabalov NP, Ivanov DO, Shabalova NN. Heterogeneity of the systemic inflammatory response in neonatal. Med. Acad. J. 2001; 1 (3): 81-90. (in Russian) 
33. Stanishevskaya OI, Fedorova ES. Comparative evaluation of the peculiarities of stress reactivity of the Russian white breed chicken with sw+ mutation and amrox in hypothermia conditions during embryonal and early postnatal periods of ontogenesis. Agricult. Biol. 2019; 54 (6): 1135-1143. DOI: 10.15389/ agrobiology.2019.6.1135rus. (in Russian)

34. Surai P, Fisinin VI. The modern anti-stress technologies in poultry: from antioxidants to vitagenes. Agricult. Biol. 2012; 4: 3-13. DOI: 10.15389/agrobiology.2012.4.3eng.

35. Weimer SL, Wideman RF, Scanes CG, Mauromoustakos A, Christensen KD, Vizzier-Thaxton Y. An evaluation of methods for measuring stress in broiler chickens. Poult. Sci. 2018; 97 (10): 3381-3389. DOI: 10.3382/ps/pey204.
36. Yabluchanskiy NI, Pilipenko VA, Kondratenko PH. Leukocyte shift index as a marker of the body's reactivity in acute inflammation. Lab. Work. 1983; 1: 60-61. (in Russian)

37. Zamaziy AA. Hemocytopoiesis of functionally active newborn calves and calves in the state of hypoxia. Theor. Appl. Vet. Med. 2018; 6 (3): 44-49. DOI: 10.32819/2018.63009.

38. Zubchenko SO, Akimova VM, Lapovetz LE. Detection donozological violations under change of integral hematological indices in patients with chronic Epstein-Barr virus infection in latent phase. Bull. Probl. Biol. Med. 2014; 4 (1/113): 125-128. Available at: https://vpbm.com.ua/ua/vpbm-2014-04-1/7214 (in Ukrainian)

\title{
Diagnostic value of integrated immunohematological indices as markers of chronic stress in laying hens
}

\author{
Yu. Osadcha \\ seledat@ukr.net
}

National University of Life and Environmental Sciences of Ukraine, 15 Heroyiv Oborony str., Kyiv, 03041, Ukraine

The study of stress in the conditions of industrial technologies of keeping laying hens and determining the level of technological stressors influence on the physiological state of poultry is a necessary condition for the development of new methods of stress prevention in choosing the best ways to keep them. The aim of the study was to determine the informativeness of integrated immunohematological indices for the diagnosis of stress-induced disorders in laying hens under the influence of technological stressors of varying intensity. Chronic technological stress was modeled by long-term keeping of laying hens at high planting density. The intensity of the stressor was determined by increasing the density of laying hens. Integral immunohematological indices were determined on the basis of an extended general blood test. It has been found that in laying hens, which due to prolonged exposure to high density were in a state of chronic stress, there is a high level of endogenous intoxication and impaired immunological reactivity, as evidenced by increased Leukocyte shift index, Immunoreactivity index, Leukocyte to erythrocyte sedimentation rate ratio, lymphocyte to monocyte ratio, heterophil to monocyte ratio. It is shown that under chronic stress in laying hens there is activation of the cellular part of the immune system, active adaptive response of white blood, as well as the predominance of delayed-type reactions over immediate-type hypersensitivity, as indicated decrease in lymphocyte-granulocyte index, general index, lymphocytic index and lymphocyte to eosinophil ratio. Thus, integrated immunohematological indices are promising markers for the diagnosis of chronic stress in laying hens.

Key words: immunohematological indices, laying hens, stress, immunological reactivity, endogenous intoxication

Osadcha Y. Diagnostic value of integrated immunohematological indices as markers of chronic stress in laying hens.

Biol. Tvarin. 2021; 23 (2): 19-25. DOI: 10.15407/animbiol23.02.019. 